This article is licensed under the Creative Commons Attribution-NonCommercial 4.0 International License (CC BY-NC) (http://www.karger.com/Services/OpenAccessLicense). Usage and distribution for commercial purposes requires written permission.

\title{
Isolated Bilateral Gastrocnemius Myositis in Crohn Disease Successfully Treated with Adalimumab
}

\author{
Salvatore Vadala di Prampero ${ }^{\mathrm{a}}$ Marco Marino $^{\mathrm{a}}$ Francesco Toso $^{\mathrm{a}}$ \\ Claudio Avellini ${ }^{a} \quad$ Vu Nguyen ${ }^{b}$ Dario Sorrentino ${ }^{a, b, c}$
}

${ }^{a}$ Department of Pathology, University Hospital of Udine, Udine, Italy; ${ }^{b}$ Department of Internal Medicine. Virginia Tech Carilion School of Medicine, Roanoke, VA, USA;

'Department of Clinical and Experimental Medical Sciences, University of Udine School of Medicine, Udine, Italy

\section{Keywords}

Crohn disease $\cdot$ Inflammatory bowel disease $\cdot$ Myositis · Adalimumab · Anti-tumor necrosis factor $\cdot$ Extraintestinal manifestations

\begin{abstract}
Extraintestinal manifestations are common in inflammatory bowel disease; however, muscular involvement in Crohn disease is rarely reported. We present a case of a 26 -year-old male with ileocolonic Crohn disease who developed sudden tenderness in both calves. Doppler ultrasound was negative for deep vein thrombosis. Magnetic resonance imaging of the gastrocnemius muscle showed high intensity signal in the muscle fibers, and muscle biopsy demonstrated nonspecific lymphocytic myositis. Other relevant laboratory results included normal antineutrophil cytoplasmic antibodies and creatine kinase as well as elevated Creactive protein, erythrocyte sedimentation rate, and anti-Saccharomyces cerevisiae IgG titer. The patient was in clinical remission, being treated with azathioprine $2.5 \mathrm{mg} / \mathrm{kg}$. Prednisone
\end{abstract}




\section{Case Reports in \\ Gastroenterology}

Case Rep Gastroenterol 2016;10:661-667

(c) 2016 The Author(s). Published by S. Karger AG, Basel www.karger.com/crg

Vadala di Prampero et al: Isolated Bilateral Gastrocnemius Myositis in Crohn Disease Successfully Treated with Adalimumab

$60 \mathrm{mg} /$ day was initiated with rapid resolution of calf tenderness; however, tenderness soon returned when the dose was tapered to $10 \mathrm{mg} /$ day. Subsequently, prednisone and azathioprine were discontinued, and adalimumab was started at standard induction and maintenance doses. The patient's symptoms resolved shortly after the first induction dose. A repeat magnetic resonance imaging of the calves -3 months after starting adalimumab - showed complete resolution of muscle inflammation. To our knowledge, this is the first case of gastrocnemius myositis - a rare extraintestinal manifestation of Crohn disease - successfully treated with anti-tumor necrosis factor agents.

(C) 2016 The Author(s)

Published by S. Karger AG, Basel

\section{Introduction}

Inflammatory bowel diseases (IBD), which include Crohn disease (CD) and ulcerative colitis, may be associated with a variety of extraintestinal manifestations (EIMs) that can cause greater morbidity than the underlying intestinal disease and may represent the first sign of IBD. Since EIMs can involve multiple organ systems, some authors believe that IBD is a systemic disorder with predominant bowel manifestations. As many as $36 \%$ of the IBD patients have at least one EIM: some correlate to the activity of bowel inflammation (joint, skin, and ocular manifestations), some to small bowel dysfunction (cholelithiasis or nephrolithiasis), while others are nonspecific disorders (osteoporosis or hepatobiliary disease) [1]. The most frequent EIMs in IBD are arthropathies (4-23\%), followed by cutaneous manifestations (2-34\%), ocular manifestations (4-12\%), hepatobiliary diseases (5-15\%), and metabolic bone diseases [2]. Muscular involvement in IBD is rarely reported in the literature [3].

\section{Case Presentation}

A 26-year-old male with a 6-year history of ileocolonic CD presented with mild diarrhea and sudden tenderness in both calves and no other symptoms. His CD at diagnosis involved the terminal ileum and cecum and was initially treated with a cycle of prednisone $60 \mathrm{mg}$ daily for 4 weeks and azathioprine $2.5 \mathrm{mg} / \mathrm{kg}$ daily. Azathioprine was then continued in monotherapy, and the patient remained in clinical remission with normal inflammatory markers (fecal calprotectin and C-reactive protein) for the following 5 years. His past medical history included only allergic rhinitis.

On physical examination, calves bilaterally were tender on palpation; no rash, skin lesion, or signs of systemic vasculitis were observed. Hematologic investigations showed elevated C-reactive protein at $14.30 \mathrm{mg} / \mathrm{L}$ (normal $0-5$ ), erythrocyte sedimentation rate at 31 $\mathrm{mm} / \mathrm{h}$ (normal 1-10), and positive anti-Saccharomyces cerevisiae Ig G [ASCA IgG] titer at 1:160. Other laboratory tests including antineutrophil cytoplasmic antibodies [c-ANCA], creatine kinase [CK], antinuclear antibodies, anti-smooth-muscle antibodies, antimitochondrial antibodies, and anti-Jo-1 antibodies were within normal limits.

Ultrasound Doppler studies of the lower extremities excluded deep vein thrombosis. Magnetic resonance imaging [MRI] of the legs showed bilateral high-intensity signal in the gastrocnemius muscle fibers beneath the muscle membrane spreading to the right flexor 


\section{Case Reports in \\ Gastroenterology}

Case Rep Gastroenterol 2016;10:661-667

(c) 2016 The Author(s). Published by S. Karger AG, Basel www.karger.com/crg

Vadala di Prampero et al: Isolated Bilateral Gastrocnemius Myositis in Crohn Disease Successfully Treated with Adalimumab

muscle of the hallux and the tibialis anterior - a picture consistent with myositis (Fig. 1). Electromyography showed neither nerve nor muscle abnormalities. Subsequently, a gastrocnemius muscle biopsy was performed, which showed nonspecific lymphocytic myositis (Fig. 2). A colonoscopy was also performed to assess intestinal disease activity, which showed few aphthous ulcers in the ileum (simple endoscopic CD score of 3 ).

The patient was started on prednisone $60 \mathrm{mg}$ daily, resulting in complete clinical remission of his myositis within a few days. After 1 month, prednisone was tapered at $10 \mathrm{mg}$ every other week. However, at the dose of $10 \mathrm{mg}$ daily, the patient experienced recurrence of symptoms with calve pain. Prednisone was increased to $60 \mathrm{mg}$ daily, and after 1 month it was slowly tapered by $5 \mathrm{mg}$ every other week. Azathioprine was maintained all along at the dose of $2.5 \mathrm{mg} / \mathrm{kg}$ daily. Once again, tapering prednisone below $10 \mathrm{mg}$ daily resulted in symptom relapse. At this point, prednisone and azathioprine were discontinued and adalimumab was initiated at regular induction $(160 / 80 \mathrm{mg}$ ) and maintenance (40 mg every other week) doses. The patient became completely asymptomatic few days after the first induction dose. Repeat MRI 3 months later did not show any significant inflammation of the gastrocnemius muscles (Fig. 3). After 9 months of adalimumab therapy with the subject still asymptomatic, azathioprine was reintroduced at a dose of $2.5 \mathrm{mg} / \mathrm{kg}$ daily, and after 3 additional months, only azathioprine was continued. 1 year after adalimumab discontinuation, the patient remained in full clinical remission from myositis while on azathioprine monotherapy.

\section{Discussion}

We report here the case of a CD patient who developed gastrocnemius myositis - apparently as an EIM - with normal CK and an elevated ASCA IgG titer. Published case reports of gastrocnemius myalgia linked to $\mathrm{CD}$ have shown similar prevalence in both genders, with patient age ranging from 19 to 50 years. Muscle histology showed granulomatous myositis in 2 cases $[4,5]$, nonspecific myositis in 4 cases $[6-8,11]$, and vasculitis in 3 other cases $[9,10]$.

Most cases, as well as our own, had normal serum levels of CK and c-ANCA. Only 1 case presented with high c-ANCA titers [11]. The main features of reported cases of gastrocnemius myalgia associated with CD are summarized in Table 1 . All cases of calf-limited myalgia reported in the literature responded to prednisolone [4, 6-12] except 1 [5]. In 2 young females, a combination treatment of prednisolone plus azathioprine or cyclophosphamide [10] seemed to be effective.

Our patient initially responded to prednisone, but his symptoms quickly relapsed after the dose was lowered below $10 \mathrm{mg} /$ day. This case appears to differ from the others since this is the first case in which ASCA positivity (frequently reported in CD) was detected. It is also the first case of gastrocnemius myositis successfully treated with an anti-tumor necrosis factor (TNF) agent.

Anecdotal reports suggest that TNF inhibitors can be helpful in the treatment of dermatomyositis and polymyositis, although other reports do not show a benefit or even show that these disorders could actually be the result of such treatment (e.g., the onset of myositis has been reported in rheumatoid arthritis patients during anti-TNF therapy) [13-15]. The myositis in IBD patients differs from the myositis resulting from other causes since it does not 
appear to be associated with an increased CK or with specific autoantibodies. It also does not show typical electromyography or histology features. Its relationship to IBD may explain why this type of myositis, but not others, might respond to anti-TNF therapy.

In conclusion, gastrocnemius myositis can be a rare EIM of CD, which may be particularly troublesome for the patient and refractory to conventional therapies. Our case report is the first in the literature that describes a case successfully managed with anti-TNF agents.

\section{Statement of Ethics}

The authors have no ethical conflicts to declare.

\section{Disclosure Statement}

The authors have no conflicts of interest to disclose.

\section{References}

1 Bernstein CN, Blanchard JF, Rawsthorne P, Yu N: The prevalence of extraintestinal diseases in inflammatory bowel disease: a population based study. Am J Gastroenterol 2001;96:1116-1122.

-2 Orchard T: Extraintestinal complications of inflammatory bowel disease. Curr Gastroenterol Rep 2003;5:512-517.

-3 Greenstein AJ, Janowitz HD, Sachar DB: The extraintestinal manifestations of Crohn's disease and ulcerative colitis in a study of 700 patients. Medicine (Baltimore) 1976;55:401-412.

-4 Ménard DB, Haddad H, Blain JG, Beaudry R, Devroede G, Massé S: Granulomatous myositis and myopathy associated with Crohn's colitis. N Engl J Med 1976;295:818-819.

-5 Diószeghy P, Molnár M, Mechler F: Muscle involvement in Crohn's disease [in Hungarian]. Orv Hetil 1994;135:1259-1261.

6 Christopoulos C, Savva S, Pylarinou S, Diakakis A, Papavassiliou E, Economopoulos P: Localised gastrocnemius myositis in Crohn's disease. Clin Rheumatol 2003;22:143-145.

-7 Shimoyama T, Tamura Y, Sakamoto T, Inoue K: Immune-mediated myositis in Crohn's disease. Muscle Nerve 2009;39:101-105.

-8 Mogul Z, Katz S, Bachman TR, Urmacher C: Isolated gastrocnemius myositis related to Crohn's disease. Gastroenterol Hepatol (NY) 2010;6:453-455.

-9 Gilliam JH 3rd, Challa VR, Agudelo CA, Albertson DA, Huntley CC: Vasculitis involving muscle associated with Crohn's colitis. Gastroenterology 1981;81:787-790.

10 Disdier P, Swiader L, Harlé JR, et al: Crohn's disease and gastrocnemius vasculitis: two new cases. Am J Gastroenterol 1997;92:880-882.

11 Hall MJ, Thomas WE, Cooper BT: Gastrocnemius myositis in a patient with inflammatory bowel disease. Digestion 1985;32:296-300.

12 Drabble EM, Gani JS: Acute gastrocnemius myositis. Another extraintestinal manifestation of Crohn's disease. Med J Aust 1992;157:318-320.

13 Labioche I, Liozon E, Weschler B, Loustaud-Ratti V, Soria P, Vidal E: Refractory polymyositis responding to infliximab: extended follow-up. Rheumatology (Oxford) 2004;43:531-532.

14 Hengstman GJ, Van den Hoogen FH, Van Engelen BG: Treatment of dermatomyositis and polymyositis with anti-tumor necrosis factor-alpha: long-term follow-up. Eur Neurol 2004;52:61-63.

15 Dastmalchi M, Grundtman C, Alexanderson H, et al: A high incidence of disease flares in an open pilot study of infliximab in patients with refractory polymyositis. Ann Rheum Dis 2008;67:1670-1677. 


\section{Case Reports in Gastroenterology}

Case Rep Gastroenterol 2016;10:661-667

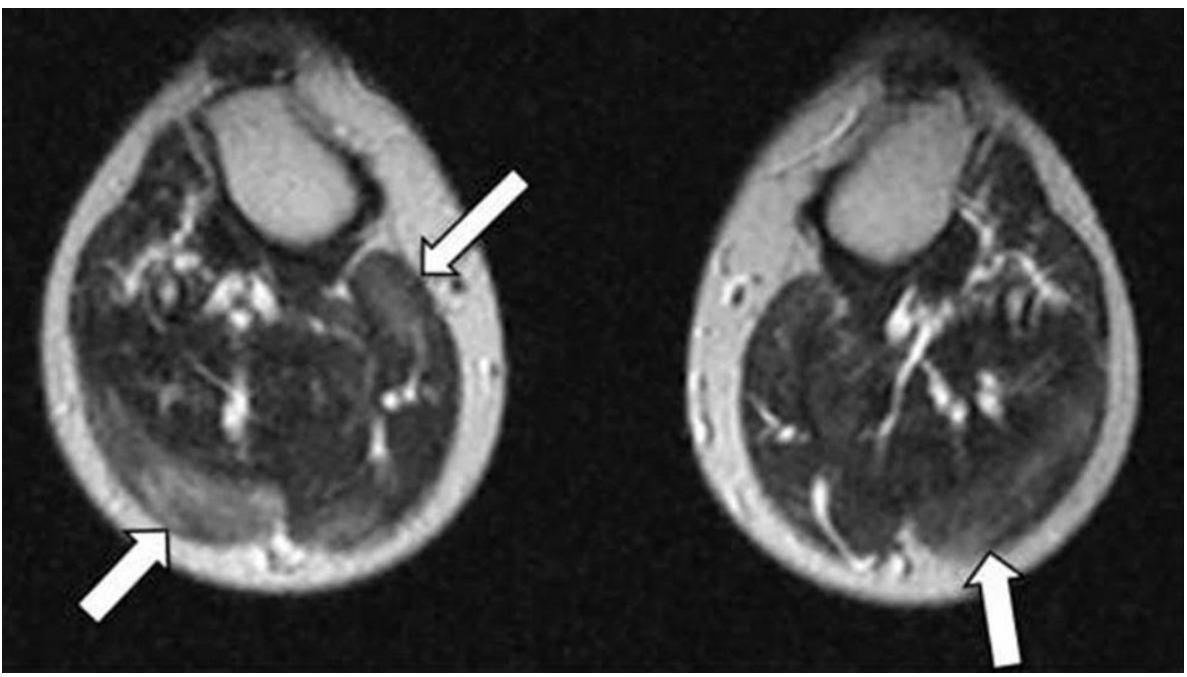

Fig. 1. Axial MRI of the calves. T2-weighted spin-echo MR images show diffuse myositis pattern involving several different muscle groups, most marked in the medial and lateral head of the gastrocnemius muscles (arrows).

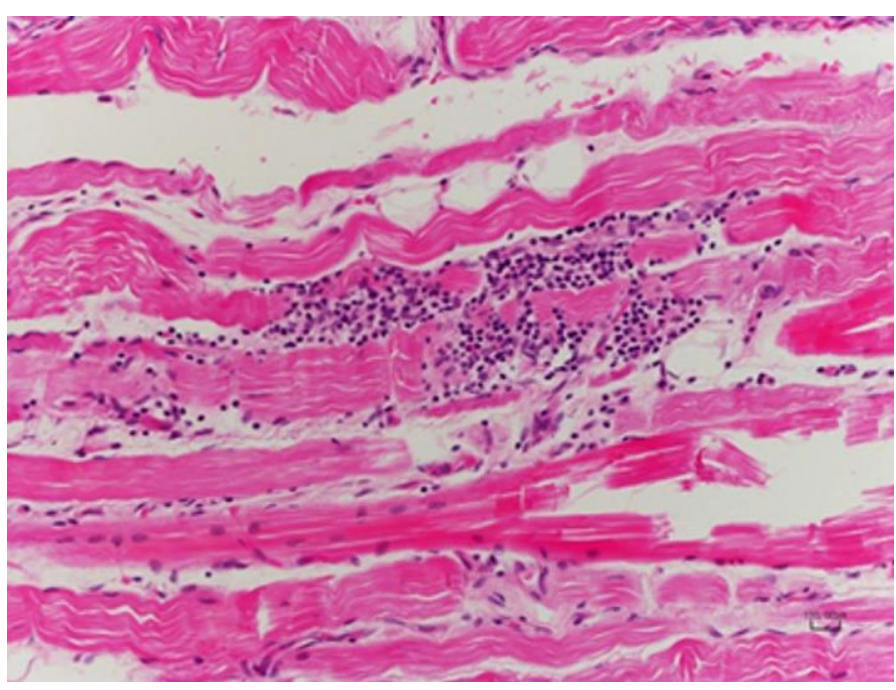

Fig. 2. Histological findings of calf muscle biopsy (HE. $\times 20)$. Lymphocytic infiltration in striated muscle cells with typical aspects of cellular regression. 


\section{Case Reports in Gastroenterology}

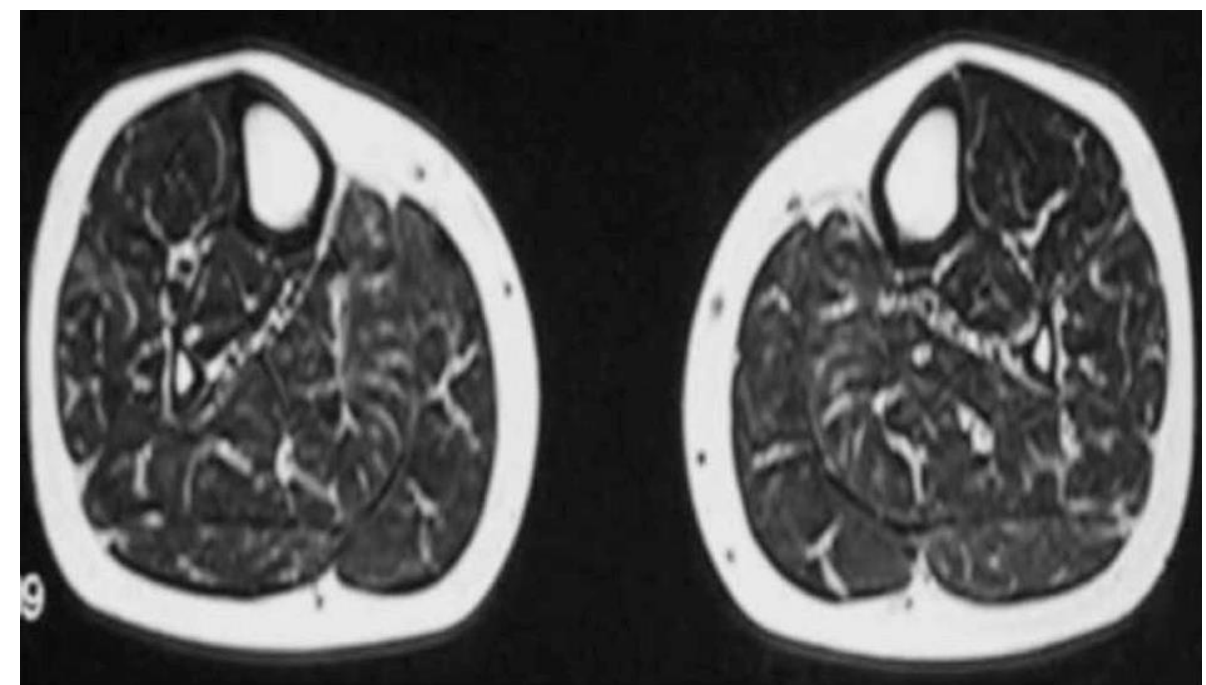

Fig. 3. Axial MRI of the calves during treatment with adalimumab. T2-weighted spin-echo MR images demonstrate the absence of inflammation in the previously involved muscle groups (for comparison, see Fig. 1). 
Vadala di Prampero et al.: Isolated Bilateral Gastrocnemius Myositis in Crohn Disease Successfully Treated with Adalimumab

Table 1. Features of reported cases of gastrocnemius myalgia in CD

\begin{tabular}{|c|c|c|c|c|c|}
\hline First author [ref.] & $\begin{array}{l}\text { Age, } \\
\text { years }\end{array}$ & Sex & $\begin{array}{l}\text { Laboratory } \\
\text { findings }\end{array}$ & $\begin{array}{l}\text { Muscle } \\
\text { histology }\end{array}$ & Treatment \\
\hline Ménard [4] & 44 & M & normal CK & $\begin{array}{l}\text { granulomatous } \\
\text { myositis }\end{array}$ & prednisolone \\
\hline Gilliam [9] & 19 & M & normal CK & vasculitis & prednisolone \\
\hline Hall [11] & 32 & $\mathrm{~F}$ & normal CK & myositis & prednisolone \\
\hline Drabble [12] & 50 & $\mathrm{M}$ & normal CK & not performed & prednisolone \\
\hline Diószeghy [5] & 41 & M & normal CK & $\begin{array}{l}\text { granulomatous } \\
\text { myositis }\end{array}$ & $\begin{array}{l}\text { no response to steroids or } \\
\text { nonsteroidal } \\
\text { anti-inflammatory drugs }\end{array}$ \\
\hline Disdier [10] & $\begin{array}{l}21 \\
26\end{array}$ & $\begin{array}{l}\text { F } \\
F\end{array}$ & $\begin{array}{l}\text { normal CK } \\
\text { normal CK }\end{array}$ & $\begin{array}{l}\text { vasculitis } \\
\text { vasculitis }\end{array}$ & $\begin{array}{l}\text { prednisolone } \\
\text { prednisolone and } \\
\text { cyclophosphamide }\end{array}$ \\
\hline Christopoulos [6] & 19 & $\mathrm{~F}$ & $\begin{array}{l}\text { normal CK } \\
\text { c-ANCA + }\end{array}$ & myositis & prednisolone \\
\hline Shimoyama [7] & 33 & $\mathrm{~F}$ & $\begin{array}{l}\text { elevated CK } \\
\text { CD68 }+\end{array}$ & myositis & $\begin{array}{l}\text { mesalamine, colon } \\
\text { surgery }\end{array}$ \\
\hline Mogul [8] & 15 & M & $\begin{array}{l}\text { normal CK } \\
\text { normal ASCA } \\
\text { normal ANCA }\end{array}$ & myositis & $\begin{array}{l}\text { methylprednisolone, } \\
\text { methotrexate }\end{array}$ \\
\hline Current report & 26 & M & $\begin{array}{l}\text { normal CK } \\
\text { elevated ASCA IgG } \\
\text { normal c-ANCA }\end{array}$ & myositis & $\begin{array}{l}\text { adalimumab, then } \\
\text { azathioprine }\end{array}$ \\
\hline
\end{tabular}

